\title{
Evaluation of prevalence and incidence of citrus slow decline disease in citrus orchards in district Layyah
}

Hafiz Muhammad Aatif ${ }^{1}$, Tauqeer Ahmad Yasir ${ }^{1 *}$, Chudary Muhammad Shahid Hanif ${ }^{1}$, Tahira Abbas ${ }^{1}$, Abdul Wahid Baloch ${ }^{2}$, Allah Wasaya ${ }^{1}$, Saqi Kosar Abbas ${ }^{1}$ and Saadia Pervaiz Lali ${ }^{3}$

1. College of Agriculture, Bahauddin Zakariya University, Bahadur Sub-Campus Layyah, Punjab-Pakistan

2. Department of Plant Breeding \& Genetics, Sindh Agriculture University, Tandojam-Pakistan

3. Department of Chemistry, University of Sargodha, Punjab-Pakistan

*Corresponding author's email: tayasir@yahoo.com

Citation

Hafiz Muhammad Aatif, Tauqeer Ahmad Yasir, Chudary Muhammad Shahid Hanif, Tahira Abbas, Abdul Wahid Baloch, Allah Wasaya, Saqi Kosar Abbas and Saadia Pervaiz Lali. Evaluation of prevalence and incidence of citrus slow decline disease in citrus orchards in district Layyah. Pure and Applied Biology. Vol. 6, Issue 2, pp664-668. http://dx.doi.org/10.19045/bspab.2017.60069

Received: 15/02/2017 Revised: 04/05/2017

Accepted: $14 / 05 / 2017$

Online First: 19/05/2017

\section{Abstract}

An assessment was accomplished, to evaluate the prevalence and incidence of Tylenchus semipenetrans (Cobb.) in district Layyah, in the year 2016. A total of 180 soil and root samples were collected from 60 localities of district Layyah in Pakistan. The analysis revealed that $46.67 \%$ of the samples were infested with the nematode. Maximum infestation (61.67\%) was recorded in tehsil Chobara followed by Layyah (43.34\%) and Karor lal-eesan (31.67\%), respectively. In tehsil Chobara nematode in soil ranged from 1,102 to 11,070 per $\mathrm{kg}$ of soil and number of females ranged from 274 to 1,202 per gram of root followed by tehsil Layyah and Karor lal-eesan ranged from 918 to 10,430 and 1,018 to 9,854 and females per gram of root ranged from 168 to 857 and 120 to 990 respectively. This information is useful to create awareness about the citrus slow decline disease and for its rapid precautionary measures.

Keywords: Citrus decline; Tylenchus semipenetrans; Soil samples; Population dynamics

\section{Introduction}

During the last few decades, citrus industry has become the largest component of agriculture in Pakistan. Citrus is grown over 199,000 hectares in Pakistan and its average yield is about 2.36 million tonnes. Average production of citrus is approximately 12.78 tons $\mathrm{ha}^{-1}$, whereas it is possible to get the yield about 18-20 tons.ha ${ }^{-1}$ [1]. Pakistan stands at 14th position as citrus producer in the world (Source: FAOSTAT). There are various biotic factors which are responsible for reduction in yield like viruses, fungi, nematodes and bacteria. Nematodes infect crops and are responsible for losses of billions of dollars annually [2]. About 50$90 \%$ citrus orchards have been infected with Tylenchus semipenetrans in USA [3].

In Pakistan citrus is mainly produced in tropical and sub-tropical areas [4]. The Punjab province is the major producer of this important fruit by sharing $94 \%$ and $96 \%$ 
of the total area and production, respectively [5]. Citrus slow decline causing 10-30\% losses in citrus trees and therefore considered as a threatening disease [6]. In the survey, 44.44 to $61.12 \%$ infestation were reported from different areas of Sargodha [7]. Similar incidence were reported by Khanzada et al. from different citrus producing areas of Punjab [8]. The infestation of nematode up to $64.93 \%$ observed in citrus orchards [9].

In 1913, Cobb [10] discovered Tylenchus semipenetrans as the causal organism of citrus slow decline disease. Neal [11] studied the relationship between Tylenchus semipenetrans and citrus trees for the first time. In Pakistan Tylenchus semipenetrans was reported in Faisalabad in 1968. The major objective of this study was to appraise the existence and occurrence of Tylenchus semipenetrans in Layyah district.

\section{Materials and methods}

During February to June 2016, survey was completed by selecting citrus orchards at various localities in all tehsils of district Layyah (tehsil chobara, tehsil kror laleesan and tehsil layyah). Samples from 180 different sites were taken from selected orchards of district Layyah. The samples after collection from each orchard were labeled and kept at $10{ }^{0} \mathrm{C}$ in plastic bags to avoid drying and were processed within seven days. An assessment of $\mathbf{J}_{2} \mathrm{~S}$ in given sample was made by opting improved Whitehead and Hemming tray method and were counted using counting dish. Identification of Tylenchus semipenetrans carried out on the basis of perinneal pattern [12] Assessment of number of females of Tylenchus semipenetrans was done by taking one gram of roots along with $20 \mathrm{ml}$ solution of sodium hypochlorite $(10 \%)$ and were blended in blender for the period of 45 seconds. Volume of suspension was increased by adding distilled water. The suspension was passed through sieves (325 mesh size) into a beaker where females were collected and counted.

The parameters were examined by using formulae given below.

Disease Prevalence $(\%)=$ No. of orchards infected/ Total no. of orchards inspected $\times$ 100

Disease Incidence $(\%)=$ Number of infected plants / Total number of plants $\times$ 100

\section{Results and discussion}

The detailed results of investigation of the whole survey of soil and root samples of all citrus orchards are described in Table 1. It is understandable from the given set of information that total $46.67 \%$ infestation with Tylenchus semipenetrans was recorded in the citrus orchards of whole district (84 out of 180 samples). Utmost infestation with Tylenchus semipenetrans was observed in tehsil Chobara (61.67\%), whereas, citrus orchards of tehsil Karor-laleesan bare minimum infestation (31.67\%). Percentages of orchards having nematode infestation in tehsil Layyah were $43.34 \%$.

As for as the population dynamic of Tylenchus semipenetrans in soil is concerned, it ranged from 1,102 to 11,070 $\mathrm{kg}^{-1}$ of soil in tehsil Chobara, 918 to 10,430 $\mathrm{kg}^{-1}$ of soil in tehsil Layyah and 1,018 to $9,854 \mathrm{~kg}^{-1}$ of soil in tehsil Karor-laleesan (Table 1). The data regarding number of females gram $^{-1}$ of root is given in Table 1 . Results revealed that citrus orchards contained females ranged from 274 to 1,202 gram $^{-1}$ of root in tehsil Chobara, 168 to 857 gram $^{-1}$ of root in tehsil Layyah and 120 to $990 \mathrm{gram}^{-1}$ of root in Karor-laleesan.

The manifestation of Tylenchus semipenetrans was observed in Layyah district for exploiting the interaction of Tylenchus semipenetrans with citrus slow decline disease. The orchards were targeted randomly from various sites of Layyah district and 5 to 20 years old orchards were selected. Total 180 samples were examined. 
Survey results showed that maximum Tylenchus semipenetrans occurrence was in tehsil Chobara (46.67\%), Layyah (43.34\%), and minimum prevalence was in Karorlaleesan (31.67\%). The survey confirms the occurrence of Tylenchus semipenetrans in Layyah district. It was first reported in citrus trees in Californian in 1912 and was described later [11]. In USA, 90-95\% of orchards were infested with Tylenchus semipenetrans [13]. Parvaiz et al. [7] arranged a survey during 2002 reported 54\% infestation of citrus nematode from Sargodha district. In the present survey, nematode density and females of roots varied in different areas. A number of factors affected Tylenchus semipenetrans density and invasion, including soil texture, temperature, host variety, $\mathrm{pH}$, soil depth, age, nutrients status and moisture. Reproductive rates of different races of nematode obviously varied with rootstock [14]. The population of Tylenchus semipenetrans will increase at temperature
$20-31{ }^{\circ} \mathrm{C}$ with maximum density at $25^{\circ} \mathrm{C}$ and very slow development at the extremes [15]. Tylenchus semipenetrans are the most important soil borne pathogens of citrus orchards [16]. Scientists had recorded the relationship between the increase in root rot disease and the occurrence of the Tylenchus semipenetrans on citrus rootstocks $[17,18]$. Tylenchus semipenetrans can be found in any soil texture, but greatest damage occurs in shallow, poorly drained soils with organic matter contents from 2-3\% [19].

\section{Conclusions}

The information received from the survey conducted in district Layyah confirmed the presence of citrus nematode in citrus orchards. The local environment and soil are also suitable for its growth. Moreover, farmers are totally unaware about this lethal pathogen. The results of this study will help the researcher and pest controlling authorities to develop strategies to control this pathogen in order to enhance citrus production in Layyah.

Table 1. Incidence and infestation of citrus nematode causes citrus slow decline disease in citrus orchards

\begin{tabular}{|l|l|l|l|l|l|l|l|l|l|}
\hline & \multicolumn{3}{|l|}{ Tehsil Chobara } & \multicolumn{2}{l|}{ Tehsil Layyah } & \multicolumn{2}{l|}{ Tehsil Karor Laleesan } \\
\hline S.No & $\begin{array}{l}\text { Tylenchus } \\
\text { Semipenetrans }\end{array}$ & $\begin{array}{l}\text { No. of } \\
\text { females }\end{array}$ & $\begin{array}{l}\text { Pop. } \\
\text { Dyna./kg } \\
\text { Soil }\end{array}$ & $\begin{array}{l}\text { Tylenchus } \\
\text { Semipenetrans }\end{array}$ & $\begin{array}{l}\text { No. of } \\
\text { females }\end{array}$ & $\begin{array}{l}\text { Pop. } \\
\text { Dyna. } \\
\text { /kg Soil }\end{array}$ & $\begin{array}{l}\text { Tylenchus } \\
\text { Semipenetrans }\end{array}$ & $\begin{array}{l}\text { No. of } \\
\text { females }\end{array}$ & $\begin{array}{l}\text { Pop. } \\
\text { Dyna./kg } \\
\text { Soil }\end{array}$ \\
\hline 1 & + & 571 & 11070 & - & 0 & 0 & + & 762 & 9210 \\
\hline 2 & + & 235 & 10341 & + & 823 & 10430 & + & 84 & 2376 \\
\hline 3 & - & 0 & 0 & + & 857 & 10192 & + & 951 & 9854 \\
\hline 4 & + & 1005 & 10960 & + & 628 & 9812 & + & 428 & 8621 \\
\hline 5 & + & 1077 & 9872 & - & 0 & 0 & - & 0 & 0 \\
\hline 6 & - & 0 & 0 & - & 0 & 0 & - & 0 & 0 \\
\hline 7 & - & 0 & 0 & - & 0 & 0 & - & 0 & 0 \\
\hline 8 & + & 981 & 8976 & - & 0 & 0 & + & 760 & 8940 \\
\hline 9 & + & 328 & 7823 & - & 0 & 0 & + & 482 & 7200 \\
\hline 10 & - & 0 & 0 & - & 0 & 0 & - & 0 & 0 \\
\hline 11 & - & 0 & 0 & - & 0 & 0 & + & 125 & 4720 \\
\hline 12 & - & 0 & 0 & + & 376 & 7236 & + & 38 & 1348 \\
\hline 13 & - & 0 & 0 & + & 59 & 1231 & - & 0 & 0 \\
\hline 14 & - & 0 & 0 & + & 76 & 918 & + & 990 & 9726 \\
\hline 15 & + & 274 & 1200 & + & 134 & 1678 & - & 0 & 0 \\
\hline 16 & + & 128 & 1243 & - & 0 & 0 & - & 0 & 0 \\
\hline 17 & + & 321 & 1700 & + & 629 & 7892 & + & 623 & 8720 \\
\hline 18 & + & 279 & 1102 & + & 813 & 8539 & + & 4810 & 6120 \\
\hline
\end{tabular}




\begin{tabular}{|c|c|c|c|c|c|c|c|c|c|}
\hline 19 & - & 0 & 0 & + & 723 & 9163 & - & 0 & 0 \\
\hline 20 & - & 0 & 0 & + & 830 & 8102 & - & 0 & 0 \\
\hline 21 & + & 88 & 2490 & - & 0 & 0 & - & 0 & 0 \\
\hline 22 & - & 0 & 0 & - & 0 & 0 & - & 0 & 0 \\
\hline 23 & + & 218 & 3000 & + & 432 & 7901 & + & 3672 & 7381 \\
\hline 24 & - & 0 & 0 & - & 0 & 0 & - & 0 & 0 \\
\hline 25 & + & 497 & 10596 & - & 0 & 0 & - & 0 & 0 \\
\hline 26 & + & 561 & 10210 & + & 527 & 9256 & + & 56 & 2372 \\
\hline 27 & - & 0 & 0 & - & 0 & 0 & - & 0 & 0 \\
\hline 28 & + & 622 & 10906 & - & 0 & 0 & - & 0 & 0 \\
\hline 29 & - & 0 & 0 & - & 0 & 0 & - & 0 & 0 \\
\hline 30 & + & 558 & 10208 & - & 0 & 0 & - & 0 & 0 \\
\hline 31 & - & 0 & 0 & - & 0 & 0 & - & 0 & 0 \\
\hline 32 & + & 600 & 8092 & + & 689 & 10100 & + & 104 & 4209 \\
\hline 33 & + & 168 & 2691 & + & 785 & 8734 & + & 309 & 7102 \\
\hline 34 & + & 203 & 3370 & + & 328 & 8657 & + & 327 & 5620 \\
\hline 35 & + & 286 & 4496 & - & 0 & 0 & - & 0 & 0 \\
\hline 36 & - & 0 & 0 & - & 0 & 0 & - & 0 & 0 \\
\hline 37 & + & 423 & 6210 & - & 0 & 0 & + & 310 & 4430 \\
\hline 38 & + & 479 & 7109 & - & 0 & 0 & + & 672 & 7108 \\
\hline 39 & + & 568 & 6807 & - & 0 & 0 & - & 0 & 0 \\
\hline 40 & - & 0 & 0 & + & 263 & 6745 & + & 751 & 6102 \\
\hline 41 & - & 0 & 0 & - & 0 & 0 & - & 0 & 0 \\
\hline 42 & - & 0 & 0 & - & 0 & 0 & - & 0 & 0 \\
\hline 43 & + & 216 & 2008 & - & 0 & 0 & - & 0 & 0 \\
\hline 44 & + & 627 & 8526 & - & 0 & 0 & + & 669 & 8120 \\
\hline 45 & + & 772 & 8701 & - & 0 & 0 & + & 304 & 6620 \\
\hline 46 & + & 97 & 3798 & + & 172 & 2019 & + & 98 & 6209 \\
\hline 47 & + & 705 & 9601 & + & 238 & 4973 & + & 41 & 2681 \\
\hline 48 & + & 804 & 7723 & - & 0 & 0 & - & 0 & 0 \\
\hline 49 & + & 165 & 2869 & - & 0 & 0 & - & 0 & 0 \\
\hline 50 & + & 119 & 2654 & - & 0 & 0 & - & 0 & 0 \\
\hline 51 & + & 510 & 6781 & - & 0 & 0 & - & 0 & 0 \\
\hline 52 & - & 0 & 0 & - & 0 & 0 & - & 0 & 0 \\
\hline 53 & - & 0 & 0 & - & 0 & 0 & - & 0 & 0 \\
\hline 54 & + & 1202 & 11002 & - & 0 & 0 & - & 0 & 0 \\
\hline 55 & + & 1190 & 10934 & - & 0 & 0 & + & 37 & 1906 \\
\hline 56 & + & 708 & 9238 & - & 0 & 0 & + & 119 & 3730 \\
\hline 57 & - & 0 & 0 & - & 0 & 0 & - & 0 & 0 \\
\hline 58 & + & 1075 & 10213 & - & 0 & 0 & - & 0 & 0 \\
\hline 59 & + & 821 & 7249 & - & 0 & 0 & + & 810 & 9103 \\
\hline 60 & - & 0 & 0 & - & 0 & 0 & + & 892 & 9854 \\
\hline
\end{tabular}

\section{Author's contributions}

Conceived and designed the experiments: HM Aatif, TA Yasir \& CMS Hanif. Performed the experiments: $\mathrm{T}$ Abbas, A Wasaya \& SP Lali. Analyzed the data: AW Baloch \& SK Abbas. Contributed reagents/ materials/ analysis tools: HM Aatif \& TA Yasir. Wrote the paper: HM Aatif, TA Yasir \& A Wasaya.

\section{Acknowledgement}

We are highly thankful to Bahauddin Zakarya University, Multan for providing financial assistance for this research work project grant vide No. DR and EL/D-248.

\section{References}

1. Anonymous (2014). Agriculture Statistics of Pakistan, Govt. of Pakistan, Ministry of 
Food and Agriculture, Food and Agriculture Division. (Economic wing). Islamabad. 12-13.

2. Sasser JN \& Carter CC (1985). Overview of the international Meloidogyne project 1975-1984. In: An Advanced Treatise on Meloidogyne Bio Control 1: 19-24.

3. Heald CM \&O'Bannon JH (1987). Citrus declines caused by nematodes. V. Slow decline. Florida Dept. of Agri. and Consumer Services. Div. of Plant Industry. Nematology Circular. 143.

4. Iqbal MH (2003). Ecology, Biology and integrated control of citrus nematode Tylenchulus semipenetrans Cobb.) the cause of slow decline in the Punjab Pakistan. PhD thesis. Deptt. of Plant Pathol. Univ. of Agri. Faisalabad.

5. Niaz AC, Maken MN \& Malik SA (2004). Native home historical background and importance of citrus fruits in Pakistan. In: Proc 1st Int Conf on Citriculture Uni Agri Faisalabad 28-29 April: 4856.

6. Verdejo-Lucas S \& Mckenry MV (2004). Management of the Citrus Nematode, Tylenchulus semipenetrans. J Nematol 36: 424-432

7. Parvez I, Mukhtar T \& Fiaz M (2003). Occurrence of citrus nematode (Tylenchulus semipenetrans) in Sargodha districts. J Res Sci 14(1): 91-95.

8. Khanzada SA, Munir A, Burney K, Hameed K \& Rehma HU (2007). Incidence and distribution of nematodes in citrus orchards of punjab causing decline. Int. Symp. on prospect of horti. Ind. in Pak.

9. Khan M, Tahir M, Munir M, Ataullah A \& Khan NH (2010). Indcidence of citrus nematode in the citrus growing areas of NWFP. Sarhad J Agri 26(2): 271-274.

10. Cobb NA (1913). Notes on Mononchus and Tylenchulus. J Washington Academics Sci 3: 287-288.

11. Neal JC (1889). Root knot disease of peach, orange and other plants in Florida due to the work of Anguillula. Govt. Print. Off. Washington.
12. Eisenback JD, Hirschmann H, Sasser JN \&Triantaphyllou AC (1981). A guide to the four most common species of rootknot nematode (Meloidogyne spp.) with pictorial key. A crop, pub.Dept. $\mathrm{Pl}$ Path.and Genetics North Carolina State University, Raleigh NC. USA 48.

13. Thorne G (1961). "Principles of Nematology" McGraw Hill Book Co Inc New York. Mani A, Dakshina, VM \& Reddy GS (1988). "Distribution of Tylenchus semipenetrans and Meleido gynejavanica in commercial citrus nurseries in Andhra Pradesh". Ind $J$ Nematol 18: 338-339.

14. O'Bannon JH \& Hutchinson DH (1974). Nematode parasites of citrus. In Luc M., Sikora RA and Bridge J (eds). Plantparasitic nematodes in subtropical and tropical agriculture. Wallingford $U K: C A B$ International 437-466.

15. O'Bannon JH, Reynold HW \& Leathers GR (1966). Effects of temperature on penetration development and reproduction of Tylenchulus semipenetrans. Nematol. 12: 483-487.

16. EL-Nouby ASM (2002). Citrus nematode problems new approaches for its control in newly reclaimed lands. M.Sc thesis Fac Agri Cairo Uni Egypt pp. 101.

17. O'Bannon JH (1968). The influence of an organic soil amendment on infectivity and reproduction of Tylenchulus semipenetrans on two citrus rootstocks. Phytopathology. 58: 597-601.

18. EL-Mohamedy RSR \& Hasab SA (2005). Response of some citrus root stocks to infection with Fusariumsolani and citrus nematode Tylenchulus semipenetrans under greenhouse conditions. Egypt. $J$ Phytopathol 33: 11-25.

19. O’Bannon JH \& Essar RP (1985). “Citrus declines caused by nematodes in Florida: I. Soil factors", Florida Department of Agriculture and Consumer Services, Division of Plant Industry, Nematol. Circular. 14: 4. 